\title{
Investigating the Contributions of International Oil and Gas Firms to Local Development in Ghana: Dilemmas and Challenges
}

\author{
Remy Nyukorong \\ General Financial Administration, Stichting Kongregatie F.I.C., Prins \\ Bisschopsingel 22, $6211 \mathrm{JX}$, Maastricht, The Netherlands
}

Doi:10.19044/esj.2020.v16n28p74 URL:http://dx.doi.org/10.19044/esj.2020.v16n28p74

Submitted: 22 July 2020 Accepted:29 September $2020 \quad$ Published: 31 October 2020

Copyright 2020 Nyukorong. R. Distributed under Creative Commons CC-BY $4.0 \quad$ OPEN ACCESS

\begin{abstract}
Ghana is relatively new to oil and gas extraction and there is little empirical knowledge about the key players in the oil and gas business, what they do to contribute to local socio-economic development, and the quandaries these firms struggle with while operating under difficult circumstances. The purpose of this study was to assess the contribution of international oil companies to local development in Ghana and to evaluate the challenges and dilemmas faced by these firms. The study adopted a qualitative, interpretive case study design that relied on face-to-face interviews and focus group discussions to gather primary data. Interview responses were analysed, compared, and categorised with the results of transcription of the focus group discussions, and later triangulated and interpreted to draw conclusions. The study revealed that most international oil companies in Ghana are transparent in reporting on their business activities and operations. Despite the efforts by these firms to support local development by funding developmental projects, paying taxes, and providing employment opportunities to local youth, international oil companies are still a target of criticism for unsatisfactory performance. Local populations would like to see extractive firms finance community infrastructural projects matching with local priority needs and focus more on impact rather than the quantity of money disbursed or the number of projects funded. International oil companies should change their engagement approach from a mere consultation to a realistic, democratic, and broad-based involvement of the publics. This study has enriched existing frameworks applied to evaluate business organisations' contributions to local development.
\end{abstract}

Keywords: Inclusive development, institutional gaps, local communities, stakeholders, sustainable development, transparency, value co-creation.

\section{Introduction}


The extractive sector within the last few decades have been one of the areas of business that has encountered the most challenges, particularly since it is facing the global energy challenge. In the last decade, there has been unprecedented impact of international business on the socio-economic advancement of many countries (Boyle \& Boguslaw, 2007; Oetzel \& Doh, 2009; Osuji \& Obibuaku, 2016). Not long ago, the United Nations have recognised this important trend by forming partnerships with countries and corporate enterprises to work together towards accomplishing the sustainable development goals (Kolk, Kourula, \& Pisani, 2017; UN, 2015).

Interestingly, the inclusive development concept has featured so significantly, and above all, with regard to the promotion of the interests and wellbeing of society, the empowerment of people on the margins of society, and the achievement of a more equal distribution of resources. While corporate organisations are increasingly thought of as bodies with huge potential and capacity to play constructive roles, traditional global companies and management research have not lived up to expectations, particularly in terms of the particularities and impact of transnational commitment in frontier markets with regard to universal participation, inclusivity, and peace promotion (Pouw \& Gupta, 2017).

Along with the difficulties involved in researching these topics in a methodical way within an environment of volatility and unpredictability (Kolk, 2016; Kolk et al., 2017), this narrow interest could be attributed to a predisposition to concentrate on the shortcomings and drawbacks of business operations. For instance, this is in relation to triggering conflict instead of encouraging peace and harmony (Lenfant, 2016), including companies' insights of their corporate social responsibility (CSR) actions and corporate citizenship advocacy which can be seen as 'greenwashing' and 'bluewashing' (Baumann-Pauly, Nolan, van Heerden et al., 2017; Elving, 2013; Frynas, 2005; Idahosa, 2002; Watts, 2005). Moreover, such studies, which are frequently published outside the field of management science, highlight the baleful effects of businesses, particularly within the oil and gas sector in economically emergent nations. These studies also document business activities that have drastically altered the environment, promoted human rights violations, and disrupted entire communities, among other factors (Boele et al., 2001; Idahosa, 2002; Sluiter, 2009; Wheeler et al., 2002).

In these circumstances, the present study concentrates on the distinctive impact of oil and gas firms to local socio-economic development in Ghana and explores the quandaries these businesses contend with when operating in difficult situations. Companies naturally have to navigate an intricate web of social and economic relationships with multi-stakeholders and manage considerable expectations from local populations (Kolk \& Lenfant, 2018). Surprisingly, companies which try to use good judgement 
and do what they should do encounter numerous technical hitches in making concrete contributions and remaining transparent regarding these activities. This is exactly on account of the huge debates around the oil and gas sector, besides the scant studies available regarding multinational firms' contributions towards local community development. The current research involves a thorough evaluation of oil and gas companies in Ghana. This researcher considered various corporate data to which he gained access; made some observations; and conducted face-to-face interviews with company executives, government officials, mining professionals, and local leaders. The researcher also facilitated focused group discussions with local people.

Ghana is an example of a country that illustrates the potentially valuable input of oil and gas firms to the process of social and economic development in society. Ghana is relatively new to oil and gas extraction. According to recent data, Ghana is ranked the 13th top producer of oil in the continent of Africa and the 47th biggest producer of oil globally (United Nations, 2016). In 2007, the Jubilee oil field was discovered and became operational after three years. Currently, the Jubilee field produces approximately 59,000 barrels of oil a day. Total petroleum revenues at the end of December 2016 stood at $\$ 247.18$ million USD (972.55 million GHC) when compared to $\$ 396.17$ million USD at the end of December 2015 (Ministry of Finance, 2017). However, notwithstanding the availability of other precious mineral deposits such as gold, Ghana occupies the $139^{\text {th }}$ position out of 188 countries; thus, it was catalogued under 'medium human development' in the Human Development Index (United Nations, 2016). Ghana is portrayed through several socioeconomic, governance as well as humanitarian dilemmas which are observed in similar emergent nations characterised by institutional voids or the lack of developed specialised intermediaries such market research companies that can analyse market information, give signals of reliability, and facilitate business transactions (Khanna \& Palepu, 1997, 2005, 2010; Khanna, Palepu et al., 2005; Kolk \& Lenfant, 2015b; Parmigiani \& Rivera-Santos, 2015).

As evidenced, this research is focused on the role of oil and gas firms and the experiences of stakeholders regarding community development projects, job creation, and tax revenues. The three thematic areas are derived from secondary sources (Fortanier \& Kolk, 2007a, 2007b; Kolk \& Lenfant, 2018), but these aspects have thus far generally been examined through utilising macroeconomic data sources, as well as through companies' selfreported information. By showing oil and gas firms' impact to local development initiatives in Ghana in the above three dimensions, emphasising not only how companies report about the three dimensions but also how these companies are seen by different parties concerned at the Western 
region of Ghana, the study offers theoretical as well as practical useful discernment concerning the marked effect of oil and gas businesses to the local community and its needs.

The specific questions dealt with after a brief presentation of the appropriate theoretical discussions and the research design in the next two sections are as follow:

RQ1: Which multinational firms are the key players in the oil and gas business in Ghana?

RQ2: What do the oil and gas firms operating in the western region do to contribute to local socio-economic development in Ghana?

RQ3: What specific dilemmas and challenges do oil and gas firms encounter whilst contributing to the development of the community?

RQ4: What can oil and gas firms do to address these dilemmas and challenges and improve their contribution to development?

Furthermore, the last section of this empirical study discusses the implications for public policy theory and practice.

\section{Literature Review}

This section discusses the contributions of oil and gas firms to local development. For decades now, numerous studies have investigated the significance of commercial activities in economically developing nations, and a great deal of consideration has been given to socioeconomic aspects (Fortanier \& Kolk, 2007b; Kolk, 2016; Meyer, 2004). In many emergent economies, there are explicit impacts of commercial activities, criticisms, and accusations. Thus, this is normally from a broader standpoint regarding international businesses contributions, and it also refers to in-depth case study narratives which disclose negative impacts of business operations on the society (Boele et al., 2001; Idahosa, 2002; Idemudia, 2007). Claims which sceptics make usually consist of a fundamental reduction of growth initiative to merely the "business agenda" (Frynas, 2005). It even sometimes represents a lopsided power relationship involving corporate establishments and interested groups (Idahosa, 2002). Multinational firms are often criticised for their inability to incorporate social justice themes such as gender equality, climate change, peace and security in their mission statements, and also deals with issues of voicelessness and the underlying causes of poverty in their settings (Hamann \& Kapelus, 2004; Idahosa, 2002; Idemudia, 2007; Idemudia \& Ite, 2006; Turner, 2006).

Moreover, several research findings have confirmed the increasing number of Multinational firms' presence in natural resource-rich nations linking this phenomenon to the declining role of the ruling government in power (Frynas, 2005; Idemudia, 2007; Mulwa, 2017). This is indicative of a situation where corporate firms may be benefitting from governance 
ineffectiveness (Reed, 2002; Watts, 2005). Incidentally, other scholars are of the view that regulatory voids (Khanna \& Palepu, 2010) may have brought about business assuming a strong political role in the state (Doh, Rodrigues, Saka-Helmhout, et al., 2017; Reinecke \& Ansari, 2016). With regard to issues of peace and conflict management, multinational firms have gained some measure of political power and authority (Ford, 2015; Mulwa, 2017). In some sense, this involves a broader literature about 'political' corporate social responsibility (Scherer et al., 2016; Whelan, 2012; Wickert, 2016). However, more detailed reviews have established how multinational firms besides grappling with the above issues, particularly in vulnerable and challenging situations, also strive to handle them in collaboration with all relevant participants (Kolk \& Lenfant, 2013, 2015b). In addition, they cocreate unique value with local communities to enrich their living conditions (Pitelis \& Teece, 2009; Prahalad \& Ramaswamy, 2004; Romero \& Molina, 2011).

Oil and gas businesses can contribute significantly to socioeconomic development in several ways: through the payment of company taxes or the provision of employment through skills and spillovers, through enhancing employees' working conditions, and through appropriate technology transfers (Andriof \& McIntosh, 2001; Boyle \& Boguslaw, 2007; Meyer, 2004; Oetzel \& Doh, 2009; Osuji \& Obibuaku, 2016; Sullivan, 2003). Besides making macroeconomic data on which such evaluations can be based, available and accessible, companies supply an increasing bulk of business information through corporate citizenship/sustainability reporting, either on official corporate websites or in separate and independent documents. Firms' perceptions of and opinions on the effects of their undertakings in developing nations are usually captured during annual reporting. However, this is a general practice in developed economies, but it is also applicable in economically emergent states (Fortanier \& Kolk, 2007b; Fortanier et al., 2011), including Africa, of which majority are in the extractive sector (Dawkins \& Ngunjiri, 2008; Hamann \& Kapelus, 2004; Kolk \& Lenfant, 2010).

On the other hand, in spite of companies' endeavours to make an impression of the accomplishments and thus be more transparent, relevant factual information is frequently not available to the local government level for decision-making purposes (Kolk \& Lenfant, 2018). This could partly be the result of the nonexistence of credible data and of the assessment methodologies used to evaluate the impact and implications of business on issues of development. In any case, facts and specifics that might have been gathered or accessible are often not made public: for example, data concerning the different kinds of people who have been employed and the reasons for hiring them, how were the people employed, nature of the 
legality and representativeness of the people hired, how these people have been hired, how development projects have been financed, and whether or not these local development initiatives meet the hopes, dreams, and expectations of the various stakeholders involved. Usually, companies mainly report on output, such as how many people are employed and the number of community projects financed, but report less on the process used and project's impact on the lives of community members (Kolk \& Lenfant, 2018). This kind of managerial approach towards development has been criticised and disapproved repeatedly (Cragg \& Greenbaum, 2002; Fortanier $\&$ Kolk, 2007b; Frynas, 2005; Idemudia, 2007). There is an argument that multinational corporations are more likely to report on human-related factors which can more easily be assessed than on political and technical matters (Fortanier et al., 2011; Kolk \& Lenfant, 2018).

Finally, and pertinent to the topic of this research paper, discussions regarding the responsibilities and contributions of multinational oil and gas companies to development likewise need to take community-firm relations into account, particularly within the oil and gas industry, since oilfields usually operate on local community land. These extractive activities have frequently brought about harsh environmental conditions and the breakdown of social life within the community. Thus, some scholars have reasoned that firms and other commercial enterprises can only facilitate meaningful sustainable development as soon as sufficient allowance have been made to the decision-making process to accommodate the interests and values of all stakeholders (Cragg \& Greenbaum, 2002). This emphasises the significance for businesses to enter into agreements with lawful, authentic, and relevant interested parties, since multinational firms are not usually firmly established within the localities where they carry out their business activities. Coincidentally, numerous complex problems emanate when identifying leaders of local communities or when dealing with culturally diverse populations (Idemudia \& Ite, 2006; Kapelus, 2002). Therefore, multinational firms may need to recognise, fully comprehend, and follow the institutional dynamics prevalent within the local settings where the business is carried out (Bird \& Smucker, 2007). The basic question that naturally arise and which must carefully be discerned is: which people are the rightful local community that multinational firms should engage with? It matters a lot how to distinguish authentic stakeholders, as well as weigh and prioritise imaginably conflicting concerns (Egels, 2005). To solve this problem, Holzer (2008) makes a sharp distinction between stakeseekers, stakeholders, and other interested persons who work hard to place innovative ideas at the heart of the corporate agenda. As a strategic approach, international oil and gas firms must form effective and supportive relationships with stakeseekers 
(Holzer, 2008). This can help to envisage the risk of costly conflicts occurring.

Notwithstanding, conflicts that thrive amongst the various interested parties' local populations may have opposing opinions concerning which type of community projects to receive funding. Also, there is the likelihood of people colliding with management team regarding the kind of extraction method to implement. In the same vein, local stakeholder groups are expected to be answerable and responsible towards multinational firms. The aspirations and expectations of the local community may be hugely high in situations of weak governance system or systemic failure. However, the availability of job opportunities is of paramount interest (Hamann \& Kapelus, 2004). Additionally, job prospects, market avenues, access to vital social services, and fairness of the tax system have been thought to carry more weight for native population than community development projects, which are considered good-intentioned but remain inaccessible with distinct actions of companies operating within undeveloped nations (Newell \& Frynas, 2007).

Thus, the current study has adopted the case study approach to explore in detail this complex network of associations, the big aspirations of people, the positive intentions of companies as well as the perceived benefits for local communities. The researcher picked some aspects of the framework proposed by Fortanier and Kolk (2007a, 2007b). Also, Kolk and Lenfant (2018) proved that the framework is directly applicable to local settings of the western region of Ghana, namely: job creation, taxes, and socioeconomic development projects, and excluding local purchases, backward linkages, size, and technology.

\section{Methods}

\section{Context of the Study}

The study was conducted in Ghana and mostly in the western region. This is the region where most oil and gas fields are situated. The research was conducted in the regional capital of the western region, SekondiTakoradi, popularly known as 'The Oil City' of Ghana (Planitz \& Kuzu, 2015) and its localities. The most salient issues in the western region of Ghana are poor infrastructure, numerous small and large-scale gold mining operations, offshore oil and gas platforms, parental neglect, poor medical care, child labour, and job-related injuries. According to UNICEF, the western region records the highest rate of girl-child marriages below the age of 15, as compared with other regions of Ghana (Government of Ghana/UNICEF, 2016). There is also widespread corruption, widespread poverty, and cross-border migration from neighbouring West African 
countries, all of which have the tendency to fuel resentment and local conflicts.

\section{Methodological Approach}

Research in any discipline is concerned with the production of knowledge to aid the development of that particular discipline. Likewise, research in the extractive industry must be focused on the advancement of responsible business practice. The objective of this paper was to investigate problems and opportunities within the oil and gas business and to generate ideas for future development. Consistent with Van de Ven's (2007) call for engaged scholarship, the author engaged respondents (selected from among the multiple stakeholders) in case study, not merely to gather information but also to co-construct and interpret the case narratives. Single qualitative research methods may offer incomplete insight, but combinations provide a rich picture of processes, successes, and situations for improvement. Thus, this involves looking at the information from different viewpoints, methods, and sources (triangulation).

In examining oil and gas firms operating in the western region of Ghana, the author used a qualitative and interpretive case study with a semistructured interview design. Yin (2009) defined a case study as an empirical survey that examines a current event within its real-life setting, particularly when the margins between event and setting are not clearly described. The case study design is particularly useful in settings where contextual conditions of the phenomenon being investigated are essential and where the investigator has no influence over the experiences as they evolve. Ritchie and Lewis (2003) perceive the basic defining characteristics of a case study as being multiplicity of views that are embedded in a specialised context. Every part of the data gathered are collated to get the best possible responses of the research question(s). Consequently, the investigator may acquire an improved understanding of why the case in point occurred as it did, and what could turn out to be valuable to examine more in-depth in future study. Considering the interpretive perspective implemented in this study and the nature of the research questions, the case study approach was regarded as the most suitable method to use since it presents an organised way to gather information, analyze data, and report the results. This, therefore, results to a good understanding of a specific phenomenon or problem in great depth. More precisely, the case study approach provides a diversity of participant viewpoints and uses several data collection methods.

As methodological challenges are abundant in studies of business and society interactions (Crane et al., 2018), there was significant room for qualitative methods to clarify motivations, meanings, experiences, and structures fundamental to business and society relations (Bass \& Milosevic, 
2018 ). Besides, this approach was appropriate for engaging with organisational stakeholders concerning business policies, impacts and challenges, and with local populations that are vulnerable to say more on politically or socially sensitive topics. Instead of testing particular hypotheses, this study's approach recognised viewpoints of significant populations and construct a narrative from Multistakeholder responses concentrating on the drivers of achievements, challenges, and dilemmas. In utilising this methodology, study outcomes emerged through a harmony of voices over several field visits and interviews.

\section{Sampling Procedure}

After over four field visits to Ghana in 2016 and 2017, the author carried out semi-structured interviews with 68 respondents, i.e., 20 oil and gas company representatives, 10 specialists and members of civil society, and 38 government and administrative officials. Purposive sampling was used to identify managerial interviewees and enlarged employing snowball techniques (Creswell \& Plano Clark, 2011; Green \& Aarons, 2002; Patton, 2002). Government authorities were purposively selected on the basis of portfolios and engagement with relevant local Multistakeholder groups. All study respondents were anonymised.

Moreover, 15 focus group discussions were conducted in 24 villages/towns with 275 people (145 men and 130 women). In order to determine the 24 mining communities and neighbourhoods where the focused-group consultations were to be conducted, a register was put together consisting of communities impacted by the oil and gas business. The researcher adopted a random sample approach subsequent upon an initial recruitment stage according to three main conditions: (i) that communities were located in a reasonably safe and sound environment, (ii) that three out of four communities were situated closer to an oil and gas field (within a radius of a maximum 15 kilometres), and (iii) that the institution in charge of logistics and information systems knew the communities/villages well for the purposes of accelerating the job of processing and issuing contracts/permits as well as creating an atmosphere of openness and trust.

Having guaranteed that potential respondents satisfied the required conditions and norms, the researcher at random picked these communities: Half Assini, Nyamekyere, Aidousuaso, Asasetre (Jomoro municipality), Nkroful, Sanzule, Esiama, Mentukwa, Adabrim (Ellembele District), Amanzule, Miami, Axim, Ankobra (Nzema East Municipality), Cape Three Points, Princess Akatakyi, Dixcove, Akwidaa (Ahanta West District), Shama, Aboadze, Supomu-Dunkwa (Shama District), New Takoradi, Effiakuma, Kwasimintim, and Anaji (Secondi-Takoradi Metropolis). 


\section{Data Collection and Analysis}

Interpretive scientists venture to obtain their data or information through direct interaction with the event being examined. In this study, the interviews, both individual and focus group, were recorded and transcribed. The research questions and a number of open-ended questions were queried in regards to which participants responded verbally. During these processes, valuable information that were related to participants' experiences emerged. The individual responses were analysed, compared, and categorised with the results of transcription of the focus group interview, and later triangulated and interpreted to draw conclusions.

An overarching interview guide was developed. This was modified based on interviewee and tested on first visit with subsequent refinements. Interviews consist of a one-to-one, qualitative, and in-depth dialogue where the scholar assumes the role of an "investigator." It means the scholar asks questions, manages the dynamics of the conversation, or participates in discussion with a particular person at a time. Consequently, in a focus group discussion, scholars take on the task of a "moderator" or "facilitator." In this framework, the scholar facilitates a group discussion among participants and this does not involve the investigator and the participants. As distinct from interviews, the investigator thus takes a secondary role, instead of a spotlight role, in a focus group discussion.

The objectives of both the interviews and focus group discussions are as follows:

1. To identify the key players in the oil and gas business in Ghana.

2. To identify the major contributions of oil and gas firms to the socioeconomic development of Ghana.

3. To identify and analyse dilemmas and challenges faced by oil and gas firms in Ghana.

4. To make recommendations as to how oil and gas firms can improve their contribution to local development.

The author conducted face-to-face interviews with company officials (both technical departments and administrative officials), decentralised local government bodies (i.e., metropolitan, municipal and district assemblies), as well as government ministries and agencies responsible for processing and issuing permits and contracts. This made it possible for the researcher to consider "to what degree" the different parties cooperated with one another, and also, how soundly/poorly stakeholders worked together.

Company representatives were interviewed in their offices in Accra and Takoradi. Interviews with civil society leaders, NGO representatives, and government officials were held in homes, workplaces, community meetings, and other places as available. Respondents varied from around 15- 
75 with most aged 25-55. Field notes were taken during interviews and focus groups discussions. Most interviews lasted between 15-45 minutes.

Apart from the interviews and focus group discussions, the author also consulted important strategy documents regarding firm policies and procedures to CSR, minutes of certain meetings, bookkeeping records, and community outreach documents.

The author took into consideration alternative explanations for our research findings. Another consideration was the critical subject of response bias, specifically concerning demand characteristics and social desirability bias. Company executives could be discreet to discuss mistakes or weaknesses. However, the author found that company executives are open to talk over challenging and difficult aspects of their operations. The author also paid keen attention to "possible or latent" motivations beneath what was spoken, triangulated across numerous interviewees, and frequently around the same interviewee on several instances. Throughout fieldwork, the author was also cautious to not interpret interviews based on the ideals or positions interviewees may have been expected to hold. Thus, what transpired is a narrative that corroborates what is described in the study's findings they consider to correctly summarise respondents' perspective.

A critical feature of data analysis in the qualitative case study is the search for meaning by means of direct interpretation of what is observed by the researchers and what is experienced and narrated by the respondents. Bogdan and Biklen (2007, p.159) defined qualitative data analysis as "working with the data, organising them, breaking them into manageable units, coding them, synthesising them, and searching for patterns". The objective of analysis of qualitative data is to notice patterns, concepts, themes, and meanings. In a research case study, Yin (2009) examined the need for searching the information for "patterns" that could expound or recognise causal associations in the information source. In the process, the investigator focuses on the complete data first, and then makes the effort to break it up and re-constructs it all over again more deeply. Categorisation aids the investigator to make similarities and differences between patterns, to think about specific patterns as well as complex threads of the information meaningfully and make sense of it.

Once data for every community/village and for each company and each dimension was collected and emerging themes (Braun \& Clarke, 2006) were found where applicable, the data set was grouped according to one of the three classifications discussed earlier (job or employment prospects, community development projects and taxes paid). Data collected were triangulated across research respondents to understand the contributions and challenges related to the operations of oil and gas firms. The author used the consolidated criteria for reporting qualitative studies (COREQ), which is a 
harmonised robustness evaluation checklist for qualitative research (Tong et al., 2007).

\section{The Research Findings and Discussion}

Research Question One: Which multinational firms are the major players in the oil and gas business in Ghana?

Table 1. Key Players in the Oil and Gas Business in Ghana

\begin{tabular}{|c|c|c|c|c|}
\hline Company & $\begin{array}{l}\text { Jubilee } \\
\text { Equity } \\
\text { Holdings }\end{array}$ & $\begin{array}{l}\text { Tweneboa, } \\
\text { Enyanra, } \\
\text { Ntomme (TEN) } \\
\text { Equity Holding }\end{array}$ & $\begin{array}{l}\text { Sankofa } \\
\text { Gye Nyame } \\
\text { (SGN) } \\
\text { Equity } \\
\text { Holding }\end{array}$ & Stock Exchange Code \\
\hline $\begin{array}{l}\text { Tullow Ghana } \\
\text { LTD }\end{array}$ & $35.48 \%$ & $47.18 \%$ & 0 & 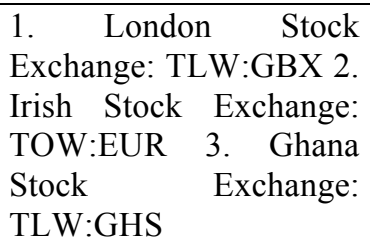 \\
\hline $\begin{array}{l}\text { Kosmos } \\
\text { Energy } \\
\end{array}$ & $24.08 \%$ & $17.00 \%$ & 0 & $\begin{array}{l}\text { New York } \quad \text { Stock } \\
\text { Exchange: NYSE:KOS }\end{array}$ \\
\hline $\begin{array}{l}\text { Anadarko } \\
\text { Petroleum } \\
\text { Corp } \\
\end{array}$ & $24.08 \%$ & $17.00 \%$ & 0 & $\begin{array}{l}\text { New York } \quad \text { Stoch } \\
\text { Exchange: NYSE:APC }\end{array}$ \\
\hline Petro SA & $2.73 \%$ & $3.82 \%$ & 0 & $\begin{array}{l}\text { Subsidiary of Central } \\
\text { Energy Fund (CEF), } \\
\text { owned by Government } \\
\text { of South Africa }\end{array}$ \\
\hline $\begin{array}{l}\text { ENI } \\
\text { Exploration \& } \\
\text { Production } \\
\text { LTD }\end{array}$ & 0 & 0 & $44.44 \%$ & $\begin{array}{l}\text { New York Stock } \\
\text { Exchange: ADR: USD } \\
\text { and STSE MIB of the } \\
\text { Milan Stock Exchange: } \\
\text { ITA: EUR }\end{array}$ \\
\hline
\end{tabular}

Source: Ghana Extractive Industries Transparency Initiative (GHEITI)/ Multi Stakeholder Group (MSG)

Research Question Two: What do the oil and gas firms operating in the western region do to contribute to local socio-economic development in Ghana?

In 2017, the major oil and gas firms doing business in the western region employed 8,296 natives, paid over 2 billion Ghanaian Cedis (GHS) to tax agencies, and contributed more than 1 billion GHS towards infrastructural and social projects, such schools, hospitals, roads, markets, provision of safe drinking water, and related projects.

Employment Opportunities: In connection with job creation, a sizeable number of persons interviewed (over 98\%) said they were content 
with the quality of employments offered with reference to remuneration and bonuses. Multinational oil and gas companies offer wages that are averagely more than triple the sum specified in the contract. Oil and gas firms also provided employees with substantial health benefits, scholarships for further education, as well as transportation facilities.

Payment of Taxes and Royalties: International oil and gas companies (IOCs) pay taxes and royalties directly to the central government. Pertaining to tax payments, the oil and gas firms disbursed 2 billion GHS in corporate to both local and national authorities. This represented approximately $81 \%$ of the aggregate amount of revenue gathered. The Petroleum Holding Fund (PHF) reconciliation report which the Finance Minister presented to the Parliament of Ghana states that,

Total petroleum receipts for 2017 was US\$540.41 million (GHC2,334.12 million), compared with US\$247.18 million (GHC'972.55 million) for 2016. The increase in receipts is mainly due to the steady increase in crude oil prices and increased production from the Jubilee and TEN fields in 2017 (Ofori-Atta, 2018, p.7).

Table 2 presents an analysis of total revenues from taxes, royalties, and other fees that were paid by multinational oil firms for the 2016 and 2017 fiscal period.

Table 2. Analysis of petroleum receipts (2016-2017)

\begin{tabular}{|c|c|c|c|}
\hline ITEM & UNIT & 2016 & 2017 \\
\hline Jubilee royalties & US\$ & $57,851,211$ & $84,257,983$ \\
\hline $\begin{array}{l}\text { Jubilee carried and participating } \\
\text { interest }\end{array}$ & US\$ & $149,936,376$ & $218,376,356$ \\
\hline $\begin{array}{l}\text { Tweneboa, Enyenra, Ntomme } \\
\text { (TEN) royalties }\end{array}$ & US\$ & - & $51,601,583$ \\
\hline $\begin{array}{l}\text { TEN carried and participating } \\
\text { interest }\end{array}$ & US\$ & - & $147,064,512$ \\
\hline Surface rentals & US\$ & 465,030 & $1,569,828$ \\
\hline Corporate income tax & US\$ & $29,546,823$ & $36,957,622$ \\
\hline PHF income & US\$ & 73,149 & 579,278 \\
\hline Gas royalties & US\$ & 379,554 & - \\
\hline \multirow[t]{2}{*}{$\begin{array}{l}\text { Gas carried and participating } \\
\text { interest }\end{array}$} & US\$ & $8,923,252$ & 4,274 \\
\hline & US\$ & 247,175,394 & $540,411,436$ \\
\hline Total petroleum receipts & GHC & $972,547,412$ & $2,334,116,929$ \\
\hline
\end{tabular}

Source: Ministry of Finance/Bank of Ghana

It is important to add that Ghana's fiscal system is a version of the concession and Production Sharing Agreement (PSA) and therefore gives 
rise to what some refer to as a royalty/tax system with state participation. Ghana has lost revenue from oil production because of this fiscal system. The country would have been better off if it had adopted the 'simplest' form of PSA compared with the fiscal system currently adopted.

It was therefore not surprising when the executive director of the Centre for Natural Resources and Environmental Management (CNREM) indicated during a press conference that the nation has lost revenue of approximately $\$ 902.45$ million USD from the oil and gas business (i.e., taxes between 2011 and 2016) due to the fact that a few of the oil firms in Ghana paid less royalties and taxes to the state than expected. The executive director of the CNREM argued that if Ghana had been practicing the PSA system, then the state should have by now been receiving more than US\$11 billion compared to the under US\$4 billion that the country has earned as petroleum income for the seven years of oil production (Allotey, 2018).

In exercising its civil responsibility, the CNREM has presented an official complaint of misdemeanour against the contracting party for underpayment of company taxes and royalties to the government of Ghana valued at USD 902.45 million for the six years of oil exploration and production from the Jubilee Oil fields off the coast of the western region of Ghana (Gale-Zoyiku, 2018). This complaint was filed at the Ghana Revenue Authority (GRA) under the Whistle-blowers Act 2006 (Act 720).

As displayed in Table 3 below, actual receipts for the period up to September 2019 indicated a decrease of US\$55.14 million when compared with the 2018 receipts. The revenue drop was largely due to a lower average realised crude oil price compared to US\$70.34 million in 2018.

Table 3. Analysis of Petroleum Receipts from January-September (20172019)

\begin{tabular}{llllll}
\hline Item & Unit & 2017 & 2018 & 2019 & $\begin{array}{l}2019 \\
2018\end{array}$ \\
& & Jan-Sept & Jan-Sept & Jan-Sept & Jan-Sept \\
\hline Royalties & US\$ & $91,760,907$ & $208,656,066$ & $187,654,914$ & $(21,001,15$ \\
& & & & & $2)$ \\
Jubilee & US\$ & $54,045,362$ & $75,908,682$ & $70,321,603$ & $\begin{array}{l}(5,587,079 \\
\text { TEN }\end{array}$ \\
& US\$ & $37,715,546$ & $69,716,782$ & $47,330,713$ & $(22,386,06$ \\
SGN & US\$ & 0 & $63,030,602$ & $70,002,598$ & $9)$ \\
$\begin{array}{l}\text { Carried \& } \\
\text { Participati }\end{array}$ & US\$ & $247,561,839$ & $395,429,812$ & $317,149,155$ & $(78,280,65$ \\
$\begin{array}{l}\text { ng interest } \\
\text { Jubilee }\end{array}$ & US\$ & $140,072,533$ & $196,736,982$ & $182,256,622$ & $(14,480,36$
\end{tabular}


1)

\begin{tabular}{|c|c|c|c|c|c|}
\hline TEN & US\$ & $107,489,306$ & $198,692,830$ & $134,892,533$ & $\begin{array}{l}(63,800,29 \\
6)\end{array}$ \\
\hline SGN & US\$ & 0 & 0 & 0 & 0 \\
\hline $\begin{array}{l}\text { Surface } \\
\text { Rentals }\end{array}$ & US\$ & 845,429 & 700,262 & 656,408 & $(43,854)$ \\
\hline $\begin{array}{l}\text { Corporate } \\
\text { Income } \\
\text { Tax }\end{array}$ & US\$ & $22,073,745$ & $117,608,720$ & $161,254,385$ & $43,645,665$ \\
\hline $\begin{array}{l}\text { PHF } \\
\text { Income }\end{array}$ & US\$ & 334,121 & $1,154,387$ & $1,697,798$ & 543,411 \\
\hline $\begin{array}{l}\text { Gas } \\
\text { Royalties }\end{array}$ & US\$ & 0 & 0 & 0 & 0 \\
\hline $\begin{array}{l}\text { Gas } \\
\text { carried \& } \\
\text { Participati } \\
\text { ng Interest }\end{array}$ & US\$ & 0 & 0 & 0 & 0 \\
\hline $\begin{array}{l}\text { Interest on } \\
\text { Late } \\
\text { Payment } \\
\text { on TEN } 3\end{array}$ & US\$ & 4,274 & 0 & 0 & 0 \\
\hline $\begin{array}{l}\text { Total } \\
\text { Petroleum } \\
\text { Receipts }\end{array}$ & US\$ & $362,580,316$ & $723,549,248$ & $668,412,660$ & $\begin{array}{l}(55,136,58 \\
8)\end{array}$ \\
\hline Total & $\mathrm{GH}$ & $1,552,129,1$ & $3,292,197,0$ & $3,436,301,6$ & $144,104,63$ \\
\hline $\begin{array}{l}\text { Petroleum } \\
\text { Receipts }\end{array}$ & $\mathbb{C}$ & 43 & 54 & 93 & 9 \\
\hline
\end{tabular}

Source: Ministry of Finance/Bank of Ghana

Socio-Economic Development Projects: For local community development ventures, nearly all oil and gas firms implemented their social investment projects in dialogue with and after consulting the regional minister, metropolitan and municipal chief executives, member of parliament, assembly members, traditional rulers, and representatives of the youth and women groups. Community investing is chiefly intended to expand infrastructure, healthcare, basic education, access to safe drinking water, agriculture, income-generating activities (IGAs) and to tackle other community needs. For example, ENI began a health project to improve the management of prevention, support, and emergency services. By easing the diffusion of knowledge regarding first-rate hygiene and health practices, the project seeks to reduce the mother-child mortality rate. The benefiting communities are those in the coastal districts of Jomoro, Ellembele, and 
Ahanta West. In these districts, there are roughly 300,000 people mainly living in isolated rural areas. 80,000 of them are children under 10 years of age and roughly 70,000 of them are young women of a childbearing age. Kosmos Energy seems to be the only oil and gas company that offers safe drinking water to people in 19 host communities, serving approximately 30,000 inhabitants. Kosmos Energy has widened the safe water project to a community senior high school at Bamiankor in the Nzema East Municipal Assembly.

Kosmos Energy, the GNPC, and Tullow Ghana have chosen some communities within the four districts to benefit from their educational infrastructure packages. Axim in the Nzema East Municipal is one of the benefiting communities. The GNPC has funded several projects at the Axim Girls Senior High School including a newly constructed twelve-unit, twostorey building (consisting of a headmistress' office, a common staff room, a library, and an eight-toilet facility). Tullow Ghana Limited also erected a student hostel that is projected to accommodate 800 students. When interviewed by this researcher, the municipal planning officer and the assistant headmaster of the school confirmed these projects. Other educational infrastructure undertakings include four newly constructed primary schools within the catchment zone. The projects are sited at the following villages: Adelkasuazo, Beyin, Nkroful-Nyaneba, and Nyamebekyere. The project elements include a headmaster's office, an Information Communication Technology laboratory, six units of classrooms, a four-toilet facility, two storerooms, and tap water and electricity for the edifices. About 100 teachers and 1,000 students were given intensive training in basic computer skills, such as Microsoft office, graphic design, blogging, and job specific skills.

Yet, international oil and gas firms are confronted with escalating criticisms regardless of their social investments impact and engagement with countless community stakeholders, and notwithstanding the honesty (such as books of first entry, human resources payroll, bookkeeping records, and contracts that were made available to the researcher) and openness of the firms' management in inviting the researcher for discussions and conversations. The section below examines the key issues mentioned is related to job provision, taxes, and development projects, respectively.

Research Question Three: What specific dilemmas and challenges do oil and gas firms encounter whilst contributing to the development of the community?

Dilemmas and Challenges Regarding Job Creation: Tensions were mounted with neighbouring local villages as few craftsmen were employed from within the local community. Many trades of technical nature entail competencies that are usually not obtained in the villages or 
communities within the immediate environs of the oil and gas fields, which leads to companies bringing in skilled workforce from the regional capital (Sekondi-Takoradi). The outstanding working conditions provided to these trained, non-native workers, together with the creation of 'developed communities' on the outer limits of the oil and gas fields (with their own comfortable hospitals, schools, and recreational grounds), produced and fuelled some bitterness (antipathy) in the local neighbourhoods. There is a large gap between the minority of well-trained staff the companies hired, who enjoy a lucrative employment and decent work conditions, alongside the sizeable mass of youth who live under deplorable and harsh conditions of poverty. Moreover, the local community does not entirely grasp the kind of the specialised competencies that IOCs need to be qualified for hire, thus suggesting the existence of communication challenges among companies and local communities. In Sanzule, for example, leaders grumbled about the fact that in their village they have over 50 young men with academic qualifications, yet not a single person was employed by any of the companies. In general, local communities' expectations for job creation have not been realised. Just 5,296 official vacancies were available in a metropolis with inhabitants of approximately 700,034 (Fiave, 2017; Ghana Statistical Service, 2012; Sekondi-Takoradi Metropolitan Assembly, 2016). However, the greater part is jobless youth just about three years after oil was discovered in commercial quantities offshore. Expressive of local communities' unrealised expectations is a statement uttered by an elder of the Axim traditional council: 'Wao, after all the loud roaring, the huge mountain (that is, the oil field) just brought forth a tiny mouse.'

Unskilled labour, typically short-term, is administrated by conscription boards consisting of local government bodies such as a civil servant, village chief, and in a few situations, the assemblyman. Normally, the recruitment boards use a quota system to reach a deal with the company executives, referring to lists of untrained young people that are prepared for each village sited within the locality of the oil field. Nevertheless, these listings or registers are usually disputed and questioned; they may either be badly drawn up (for instance, lacking in transparency making it possible for individuals to register regardless of the fact that these people are nonnatives), or are purely ignored (specifically, persons who are not captured by official records get the job through networks and relations with local representatives). Semi-structured interviews showed that the list method, even though highly regarded and esteemed in theory, is not used consistently. Only a small number of IOCs gather information on the place of origin of company workers or utilise record of untrained personnel that were registered transparently by each local community within the vicinity of the oil fields. 
Dilemmas and Challenges in Relation to Taxes: The proportion of proceeds from oil and gas companies paid to the authorities at the local levels is small relative to what the central government gets. Corporate taxes paid to local entities correspond to a minute fraction of the overall amount of money disbursed by IOCs in respect of taxes, levies, and social security contributions. In 2016, for instance, Kosmos Ghana paid \$8,531,557 USD (approximately 29.9 million GHS) in taxes, training, surface rentals, royalties, and licence fees to the central government, whereas they paid 'only' 5 million GHS as corporate taxes to the district and municipal authorities. This corresponds to $0.7 \%$ of all the payments made. Typically, yearly corporate tax paid to the district and municipal authorities fluctuates between one to four percent of the levies, taxes, royalties, and social security deductions IOCs pay to the central government. Additionally, the focused group meeting showed that community representatives were not informed about the monies paid to district and municipal authorities.

\section{Dilemmas and Challenges Regarding Socio-Economic} Development Projects: Community development projects do not always correspond to local priorities, and resources have either been misappropriated or wasted by corrupt local officials. In spite of many remarkable accomplishments, the greater part of these development projects has failed to provide sustainable results to local development questions. Simultaneously, IOCs such as Kosmos Energy that applied a consultative structure to engage governmental officials and local communities to prevent one-sided execution of community development projects were unsuccessful in effectively addressing inhabitants' expectations. Basically, there are two key reasons that explain this deficiency: (a) the participation of local councillors in the management board of this consultative structure, and (b) poor management. Local councillors frequently misuse the power given to them to make important decisions practically unilaterally, such as which specific projects should be funded, and which local businesses will take part in the execution of the project. These kinds of arrangements do not create a proper context for sufficient dialogue among the various stakeholders. Instead, they only serve as an arena to endorse the personal interests of some local councillors, thus fuelling tensions among ordinary villagers. In spite of the company's setting up of these consultation structures, this study's meetings and interviews disclosed that people are conferred with or talked to but do not wholly contribute in an effective manner to project implementation and the allocation of resources (funds). This clear lack of ownership and flawed involvement is usually the main cause of misunderstandings and conflict between local communities and corporate establishments. Community development projects sponsored by IOCs usually do not adequately consider the local-political concerns and are 
burdened by an inadequate knowledge of the conflicts and tensions they might produce.

Additionally, a number of development schemes undertaken by IOCs can be described as self-serving. For instance, constructing a wall barricade over a local police station gives the company the assurance that it will enjoy the services of the police if any security problems arise. Propitiatory or expiatory sacrifices, which can be categorised as community development, may well be considered community investments that immediately aid the acquisition of a social license to operate (SLO). A project of this kind, although pleasing to traditional leaders, cannot contribute to holistic local development. In certain situations, business firms use units or associations from inside their specific corporate group to conduct extractive activities. A lot of the investments are linked to infrastructure, mostly hardware, instead of activities focused on promoting empowerment, developing leadership skills, or even building capacity.

Furthermore, there are some villages/towns and districts that have benefitted more than others. The Ahanta West and Nzema East districts, for instance, have profited from major social investment from IOCs in the spheres of water supply, health services, education, and economic development to the disadvantage of other zones or districts. In summary, the development models adopted by some IOCs in Ghana do not seem to contain a long-term element, are not viable, are not inclusive, and do not support institution building and development. In a focused group meeting in Jomoro, residents criticised the action that a particular corporate body sponsored the construction of too many borehole projects, despite the fact that a lot of families in this community do not have clean drinking water, since these wells were not properly drilled. There were many examples where the services of an incompetent company were used for the implementation of the infrastructure project, and therefore the company could not deliver. This strained the relationships between the foreign and the community. Additionally, in cases where projects are effectively carried out from an expert perspective, some IOCs are inclined to concentrate and report on quantity instead of the impact of the projects, such as whether the community really gains access to potable water, i.e. whether the water meets drinking water quality standard, or whether the community's well-being and healthiness is enhanced.

While nearly all of the aforementioned matters (chiefly the tax issue) are particularly challenging and difficult, this study indicates that the majority of IOCs viewed these social and political issues from a managerial and technical viewpoint. A seeming lack of acknowledgement and full understanding of the intense community resentment, local power dynamics, and chronic deprivation that manifested in these local communities was 
observed. Also, the extent of community expectations (both tangible and intangible) with respect to politician not living up to the expectations of the ordinary people was misjudged and taken too lightly. A number of business executives seemed condescending, referring to reports and statistics rather than genuinely listening to complaints villagers articulated. For example, IOCs' leadership are well-informed about the 'clientelist' practices and elevated corruption levels of local elected executives, but they fail to take concrete actions to eliminate them. As one director expressed, 'We are aware the snake is poisonous, therefore we make every effort not to allow it to bite us.' Another administrator admitted to being completely aware of local-level corruption but 'found it difficult to go through due process or other possibilities because local authorities are elected persons.' Therefore, the above assertions highlight the complexity of the relationships between company executives, communities, and corrupt local elected politicians.

Research Question Four: What can oil and gas firms do to address these dilemmas and challenges and improve their contribution to development?

Dealing with "high community expectations" against the background of the leadership's failure to deliver vital amenities to its people does not absolve corporate entities of being honest and transparent regarding the magnitude of their social responsibility. On the whole, it is necessary that international oil and gas companies become more aware of cultural and social sensitivities in their engagement with the leaders of the local community. In this respect, it is apt for IOCs to take on an empathic-style communication model rather than a business-like style, as has been demonstrated so far. Readily allowing corrupt executives to agree on task distribution or the society development financing deprived of their involvement in the name of democracy for the reason that these officials are selected representatives may not be effective. It may only fuel resentment and tensions. Therefore, it is crucial to not only concentrate on the 'what' (and the statistics) but also on the 'how'. It is equally important that international companies embrace an all-encompassing developmental approach as well as concentrate on the quality of relationships.

To be more specific, a few recommendations are presented below regarding the three main dimensions on which international oil and gas companies report (that is, community development projects, paying taxes, and employment provision) based on the author's analysis.

With Respect To Taxes: International oil and gas companies should be transparent on exactly how much money is paid to each local authority unit. Companies in the extractive sector should also openly indicate the basis on which tax computations were done. It is not sufficient to simply pay taxes as a contractual necessity. Furthermore, it is prudent for multinational firms 
to desist from interfering in local political matters. Companies need to precisely demonstrate the specific sums of money paid to local, district, municipal, and national authorities. Along these lines, international companies need to animate both the local and civil society superiors to advocate and insist on transparency from the powers that be and require accountability as well as answerability regarding the apportionment of tax proceeds. Although tax returns allotment and its redeployment to decentralised agencies is a core mandate of central government, extractive firms should take note of the fact that local communities normally regard extractive companies as the ruling government's allies who therefore have scant concern and understanding for their needs.

Pertaining to Employment/Hiring Provision. It is greatly advocated that extractive firms should gather and manage dependable data of workers' places of origin so as to work out the job engagement issue which is so problematic. Concerning unqualified employment, it may perhaps be similarly prudent to straightforwardly include every community or settlement within the oil and gas production vicinity in the decision-making process. Extractive firms could also draft a comprehensive system by which a register or directory can be prepared and communicated to all participants and providing the opportunity for affected local populations to give their ideas. This participatory approach could take place by way of discussions with opinion leaders provided that they are legitimate and respected leaders who are genuinely concerned about the welfare of the people. International oil companies should not exclusively confer with 'self-styled' or 'selfproclaimed' leaders but should also listen to and, when practicable, go along with ordinary villagers' hopes and grievances. Consequently, it is necessary that extractive companies should not simply depend on the municipal or district assembly for the provision of employment; while a number of assembly members have been nominated, they usually exhibit unfaithfulness and high levels of corruption. As a final point, local community members have appealed to IOCs to get involved in capacity-building schemes and vocational training programmes to prepare youth to gain access to skilled employment.

Socio-Economic Development Projects: It is essential that extractive firms should finance community development schemes corresponding to local priority needs and concentrate more on impact rather than the quantity of money disbursed or the number of projects funded. In that regard, it might be prudent to perform project impact assessments and circulate the results to all stakeholders. Extractive firms should also move away from naive consultation to authentic, effective, and broad involvement of all stakeholders. Moreover, when discussing with local groups, it might be useful for international firms not to think that communities speak en masse. 
If at all possible, every age group, gender, and ethnic categories should be fully represented on an advisory board with complete decision-making command over how to fairly distribute funds and resources committed to community development. Extractive firms should draw up tailored policies to sidestep corrupt officials and local representatives prone to hindering the efficient implementation of projects. This will prevent or minimise the occurrence of conflict-of-interest situations. Additionally, this study recommends that IOCs should form partnerships with both local and intercontinental non-governmental organisations to make sure that development projects are responsive to gender and conflict dynamics, carefully planned, and effectively managed.

Report of Corporate Social Responsibility: In connection with the issue of informing and reporting, it might be helpful for extractive companies (particularly IOCs) to demonstrate greater transparency and accountability in the manner in which development projects are undertaken and the reasons for choosing a specific project and funding instrument (through direct implementation, through a non-governmental organisation, or via a multiactor fund). International oil and gas companies in Ghana are expected to accomplish excellent results provided they work with care, give honest report covering business dealings and relationships with resident authorities. They should also accept the fact that contacts and familiarity with unethical leaders could destroy their authentic endeavours in building trustworthy relationships with local publics. The existing literature has confirmed that corruption is one feature of bad governance, and it is not likely to be stamped out unless accompanied by fundamental institutional reform and a change in people's belief systems and mind-sets (Bentzen, 2012; Hope \& Chikulo, 2000; Meon \& Sekkat, 2005; Ogundiya, 2010; Suleiman \& Karim; Tanzi, 1998).

Table 4. Summary of challenges and suggestions for each aspect investigated

\begin{tabular}{|l|l|l|}
\hline Aspect & Challenge & Suggestions \\
$\begin{array}{l}\text { investments in } \\
\text { terms } \\
\text { development } \\
\text { projects }\end{array}$ & $\begin{array}{l}\text { Community investments } \\
\text { initiated and funded by } \\
\text { IOCs have not met the } \\
\text { urgent needs and priorities } \\
\text { of the various societies and } \\
\text { villages in which these } \\
\text { foreign companies do } \\
\text { business; there seems not } \\
\text { to produce tangible results, } \\
\text { and projects are not } \\
\text { sustainable. }\end{array}$ & $\begin{array}{l}\text { IOCs should include CSR } \\
\text { economic development schemes so as to } \\
\text { make certain that the pressing needs of the } \\
\text { local populations are well-considered. } \\
\text { broadcast the impact of all community } \\
\text { investments initiated and funded. To do } \\
\text { this more effectively, IOCs should } \\
\text { concentrate on the quality in preference to } \\
\text { the number of investment projects. } \\
\text { With regard to community }\end{array}$ \\
\hline
\end{tabular}




\begin{tabular}{|c|c|c|}
\hline Aspect & Challenge & Suggestions \\
\hline & & $\begin{array}{l}\text { engagements, IOCs should change their } \\
\text { engagement approach from easy } \\
\text { consultation to realistic, democratic, and } \\
\text { broad involvement of the publics. } \\
\text { Multinational firms should not also } \\
\text { imagine that local populations all express } \\
\text { the same opinion or be of one mind. } \\
\text { - IOCs must identify concrete } \\
\text { means to avoid local corrupt authorities } \\
\text { and selected executives who may have the } \\
\text { tendency to hinder and frustrate the } \\
\text { proper functioning of development } \\
\text { schemes, and completely eschew self- } \\
\text { interested behaviours. } \\
\text { - It is critical to develop } \\
\text { cooperation and good relationships with } \\
\text { all stakeholders such as local and national } \\
\text { interested parties as well as external } \\
\text { parties to a) make sure that investments } \\
\text { made in local communities are properly } \\
\text { planned and accomplished and b) keep in } \\
\text { mind that development ventures are } \\
\text { susceptible to disagreements and gender } \\
\text { dynamics. }\end{array}$ \\
\hline Taxes & $\begin{array}{l}\text { The percentage of taxes } \\
\text { paid to local authorities by } \\
\text { IOCs is low. This } \\
\text { encourages and increases } \\
\text { resentment and bitterness } \\
\text { of local populations and } \\
\text { thus creates unnecessary } \\
\text { disputes. }\end{array}$ & $\begin{array}{l}\text { - It is important to be transparent } \\
\text { about exactly how much money is paid to } \\
\text { government tax agencies and how much is } \\
\text { paid to district and municipal tax } \\
\text { agencies. } \\
\text { IOCs to be crystal clear regarding the } \\
\text { reasons underpinning their tax } \\
\text { computations to avoid misunderstandings. } \\
\text { - IOCs should be cognisant of the } \\
\text { fact that local populations receive } \\
\text { extraordinarily little money (not more } \\
\text { than } 1 \% \text { ) from the total amount of monies } \\
\text { disbursed to the central administration as } \\
\text { taxes. } \\
\text { - Companies should be sensitive to } \\
\text { the fact that local populations usually } \\
\text { regard IOCs as allies to the governing } \\
\text { party with not much concern for local } \\
\text { people developmental needs. } \\
\text { l Companies should support youth } \\
\text { leaders to insist on transparency from } \\
\text { local officials and press for accountability } \\
\text { concerning the distribution of tax incomes } \\
\text { received from oil and gas firms. }\end{array}$ \\
\hline
\end{tabular}




\begin{tabular}{|c|c|c|}
\hline Aspect & Challenge & Suggestions \\
\hline $\begin{array}{l}\text { Job } \\
\text { provision/creation }\end{array}$ & $\begin{array}{l}\text { Multinational companies } \\
\text { do not employ adequate } \\
\text { workforce (both skilled } \\
\text { and unskilled) from within } \\
\text { the local communities. }\end{array}$ & $\begin{array}{l}\text { - IOCs should gather and manage } \\
\text { reliable information or data concerning } \\
\text { the places from which employees come. } \\
\text { - IOCs should not solely depend } \\
\text { on nominated officials for employment } \\
\text { provision. } \\
\text { - For jobs that do not require } \\
\text { expertise or specific skill, it is important } \\
\text { to include all villages affected by the } \\
\text { extractive activities to take active role in } \\
\text { the decision-making process and to figure } \\
\text { out a method on the basis of which a list } \\
\text { can be compiled and shared with } \\
\text { interested parties based on transparency, } \\
\text { and give to all affected villages and } \\
\text { districts the opportunity to offer their } \\
\text { contributions. } \\
\text { I For skilled employments/careers, } \\
\text { IOCs should sponsor and finance } \\
\text { vocational and technical training } \\
\text { programmes for the youth to enable them } \\
\text { to access those specialised jobs. }\end{array}$ \\
\hline
\end{tabular}

Source: Author

\section{Conclusions and Recommendations for Practice}

This research explored the contributions of international oil and gas extraction firms towards community development in the western region of Ghana by examining three aspects: community development ventures initiated and funded, employment opportunities offered to the youth, and taxes/royalties paid to both local and national revenue authorities. Apart from the above, the study also assessed the challenges that IOCs grappled with while operating under difficult circumstances, promoting community economic and social development, and giving an account on these issues. The researcher obtained information from the Multinational Oil and Gas firms, which revealed transparency in their reporting to the general public as well as letting the researcher to review minutes, protocols, and obtained duplicates of bookkeeping records. The research likewise involved field observations as well as focused-group consultations in mining communities. The researcher also held semi-structured interviews with foreign companies' representatives, non-governmental organisations, mining communities, government authorities, and experts and individuals from local organisations. By probing the issues directly from a firm and stakeholder point of view, it was possible for the researcher to review how multinational companies contributed towards inclusive development and empowerment of local 
populations within the framework of societal and community expectations. Based on the above, the researcher modified prevailing research reports that depended on either self-reported Company information or stakeholder experiences and views solely, or that applied large-scale data from a more multidisciplinary approach.

In spite of companies' attempts to support local development by sponsoring or financing development projects, paying taxes and royalties, and employing local staff, oil and gas firms are still a target of criticism for unsatisfactory performance. Table 4 above presents a summary of the major operational challenges in each aspect, including some suggestions on how to make progress and improve transparency. The table also offered an explanation on the difficulties encountered and on stakeholders and local communities' experiences and views of what oil and gas firms do, together with their political role with regard to elected officials and government authorities. More likely, this will provide mental stimulation regarding the intrinsic and fundamental partisan nature of development and socioeconomic undertakings by foreign firms that intend to do business responsibly. In this way, the paper specifically contributes to the more theoretical discussion about political CSR, accentuating the value of oil and gas firms engaging with authentic, incorrupt, and honest stakeholders to promote participatory decision-making and good governance while contributing to local development. Long-term plans of action in these contexts should thus be drawn up and designed differently than they are elsewhere.

As illuminated in the current empirical paper, the impact of business on development has commonly been assessed by means of objective data comprised of numbers and ratios provided by firms. Nevertheless, the key subject of this study is that the question of what multinational firms do may not be as significant as how and with whom these activities are carried out. Even though the majority of firms admit that undertaking development single-handedly is hugely difficult, undertaking it with the wrong development partners may not support businesses in realistically and efficiently engaging development issues. Conversely, it could have the result of dissipating scant resources that could have been used more profitably. Additionally, successful outcomes could have been realised with regard to perceived large-scale development with a lean budget or not many activities. Candid and open exchange of ideas is indispensable; and not only through formal narration of figures and percentages but also by regular contacts with the local community members characterised by sincerely paying attention to the complaints of the people and appreciating their views.

The study moreover enriched existing frameworks applied to evaluate or assess business organisations' contributions to local development. Nearly all development frameworks address the 'what' and the visible, output- 
related outcomes connected to the socioeconomic sphere of influence (i.e., job-creation or employment, taxes, and community development projects). This empirical study highlights the significance of separating the firm's involvement in the socio-economic aspects of the local populations and urges multinational companies to include governance and community-based responses whilst reviewing and collaborating their support towards local development. Beyond the Ghana case, the results of this study moreover indicate that businesses' impacts on local community development are mostly political rather than technical in nature, and that a positive impact demands specialised skillsets and human capital, such as sensitivity and empathy. Thus, it is crucial that multinational extractive firms should thoughtfully and carefully consider these qualities when developing strategic approaches and designing business activities.

Therefore, directors and supervisors must be open about the scope and extent of their CSR, as well as the priorities of the local and central government authorities and become skilled at handling the intricate network of relationships and associated corrupt institutions. Multinational companies should be mindful of the various understandings of what exactly 'local' denotes so as to abstain from damaging conflicts with the host societies.

Intriguingly, while the oil and gas fields reported in this research were all jointly owned by the government, the local people seem not to be aware of it. Moreover, local people did not find it important to know whether these foreign companies were small or large, private firms that owned stocks or the countries where these firms originate, because the oil and gas fields were seen to be alien.

Somewhat surprisingly, the study holds immediate and direct consequences for international companies conducting business in foreign countries, as well as for their relationships with local communities. Table 4 above is also extremely important for transnational companies that are operationalising their CSR agendas within their local branches (Jamali, 2010), particularly in complex environments where a great deal of discernment and understanding are necessary, concurring with the latest review of the most recent developments in business and management publications (Pisani et al., 2017).

This empirical study also has relevant implications for public policy theory and practice. Governments may contemplate offering incentives to companies involved in the oil and gas business by means of participation in partnerships and risk-sharing arrangements to anchor firms' hard work and encourage all-encompassing and sustainable community development. Multinational firms have a duty to supply funding in support of development projects and collaborate with legally recognised homegrown nongovernmental organisations to learn and gain better understanding of the 
local politics. Under these conditions, multinational firms would undoubtedly give careful thought as to how they can support local inclusive development (Pouw \& Gupta, 2017) as many ways possible. The three aspects (investments in local development projects, payment of taxes and jobs created) are critical for global endeavours in fostering the United Nations Sustainable Development Goals.

\section{References:}

1. African Vault (2018). Top 20 oil producing countries in Africa. https://www.africanvault.com/oil-producing-countries-in-africa/.

2. Allotey, G.A. (2018). Ghana lost over $\$ 900 \mathrm{M}$ in oil royalties, taxes Think Tank. https://citinewsroom.com/2018/04/04/ghana-lost-over900m-in-oil-royalties-taxes-think-tank/.

3. Anadarko Petroleum Corporation (2018). Ghana fact sheet. https://www.anadarko.com/Operations/Upstream/Africa/Ghana/

4. Andriof, J., \& McIntosh, M. (Eds.) (2001). Perspectives on Corporate Citizenship, Greenleaf Publishing.

5. Bass, A.E., \& Milosevic, I. (2018). The ethnographic method in CSR research: The role and importance of methodological fit. Business \& Society, 57(1),174-215. https://doi.org/10.1177/0007650316648666

6. Baumann-Pauly, D, Nolan, J., van Heerden, A., \& Samway, M. (2017). Industry-specific multi-stakeholder initiatives that govern corporate human rights standards: Legitimacy assessments of the Fair Labour Association and the Global Network Initiative. Journal of Business Ethics, 143(4),771-787. https://doi.org/10.1007/s10551016-3076-z

7. Bentzen, J.S. (2012). How bad is Corruption? Cross-country evidence of the impact of corruption on economic prosperity. Review of Development Economics, 16(1), 167-184. https://doi.org/10.1111/j.1467-9361.2011.00653.x

8. Bird, F., \& Smucker, J. (2007). The social responsibilities of international business firms in developing areas. Journal of Business Ethics, 73(1),1-9. DOI: 10.1007/s10551-006-9192-4

9. Bogdan, R. C., \& Biklen, S. K. (2007). Qualitative research of education: An introductive to theories and methods (5th ed.).Allyn and Bacon.

10. Boele, R., Fabig, H., \& Wheeler, D. (2001). Shell, Nigeria, and the Ogoni. A study in

11. unsustainable development: I. The story of Shell, Nigeria, and the Ogoni people - environment, economy, relationships: conflict and 
prospects for resolution. Sustainable Development, 9(2),74-86. https://doi.org/10.1002/sd.161

12. Boyle, M., \& Boguslaw, J. (2007).Business, poverty, and corporate citizenship: naming the issues and framing solutions. Journal of Corporate Citizenship, $0(26), 101-120$. https://www.jstor.org/stable/jcorpciti.26.101

13. Braun, V., \& Clarke, V. (2006). Using thematic analysis in psychology. Qualitative Research in Psychology, 3(2),77-101. DOI:10.1191/1478088706qp063oa

14. Cragg, W., \& Greenbaum, A. (2002).Reasoning about responsibilities: mining company managers on what stakeholders are owed. Journal of Business Ethics,39(3), 319-335. https://doi.org/10.1023/A:1016523113429

15. Crane, A., Henriques, I., \& Husted, B.W. (2018). Quants and Poets: Advancing methods and methodologies in business and society research. Business \& Society, 57(1), 3-25. https://doi.org/10.1177/0007650317718129

16. Creswell, J.W., \& Plano Clark, V.L. (2011). Designing and conducting mixed method research (2nd edn). Sage.

17. Dawkins, C., \& Ngunjiri, F. W. (2008). Corporate social responsibility in South Africa. A descriptive and comparative analysis. Journal of Business Communication, 45(4), 286-307. https://doi.org/10.1177/0021943608317111

18. Doh, J., Rodrigues, S., Saka-Helmhout, A., \& Makhija, M. (2017). International business responses to institutional voids. Journal of International Business Studies, 48(3), 293-307. https://doi.org/10.1057/s41267-017-0074-z

19. Egels, N. (2005). CSR in electrification of rural Africa: the case of ABB in Tanzania. Journal of Corporate Citizenship,18,75-85. https://www.jstor.org/stable/jcorpciti.18.75

20. Elving, W.J.L. (2013). Scepticism and corporate social responsibility communications: The influence of fit and reputation. Journal of Marketing Communications, 19(4), 277-292. https://hdl.handle.net/11245/1.407555

21. Enipedia (2018). Eni's activities in Ghana.https://www.eni.com/enipedia/en_IT/internationalpresence/africa/enis-activities-in-ghana.page

22. Fiave, R.E. (2017). Sekondi-Takoradi as an oil city. Geography Research Forum, 37, 61-79.

23. Ford, J. (2015). Perspectives on the evolving "business and peace" debate. Academy of Management Perspectives,29(4), 451-460. https://doi.org/10.5465/amp.2015.0142 
24. Fortanier, F., \& Kolk, A. (2007a). On the economic dimensions of CSR: exploring Fortune Global 250 reports. Business and Society, 46(4), 457-478. https://doi.org/10.1177/0007650306296088

25. Fortanier, F., \& Kolk, A. (2007b). Multinationals perceptions of their economic and social impacts. In R. Sinkovics, \& Y. Yamin (Eds.), Anxieties and Management Responses in International Business, Palgrave MacMillan, Basingstoke, pp.100-115.

26. Fortanier, F., Kolk, A., \& Pinkse, J. (2011). MNEs and global CSR standards: Harmonization in CSR reporting. Management International Review, 51(5), 665-697. https://doi.org/10.1007/s11575-011-0089-9

27. Frynas, J. G. (2005). The false development promise of corporate social responsibility: evidence from multinational oil companies. International Affairs, 81(3), 581-598. https://doi.org/10.1111/j.14682346.2005.00470.x

28. Gale-Zoyiku, K. (2018, April 4). How Ghana lost US $\$ 902.45 \mathrm{~m}$ in oil royalties, taxes between 2011 and 2016. Goldstreet Business.https://goldstreetbusiness.com/business/how-ghana-lostus902-45m-in-oil-royalties-taxes-between-2011-and-2016/

29. Government of Ghana \& UNICEF (2016). Profile of the Western region of

Ghana. https://www.unicef.org/ghana/P1417_unicef_ghana_WESTERN_WE B.pdf

30. Green, A.E., \& Aarons, G.A. (2011). A comparison of policy and direct practice stakeholder perceptions of factors affecting evidencebased practice implementation using concept mapping. Implementation Science, 6(1), 104. doi: 10.1186/1748-5908-6-104.

31. Hamann, R., \& Kapelus, P. (2004). Corporate social responsibility in mining in Southern Africa: fair accountability or just greenwash. Development, $47(3)$,

85-92. https://doi.org/10.1057/palgrave.development.1100056

32. Holzer, B. (2008). Turning stakeseekers into stakeholders: a political coalition perspective on the politics of stakeholder influence. Business \& Society, 47(1), 50-67. https://doi.org/10.1177/0007650307306341

33. Hope, K. R., \& Chikulo, B.C. (Eds.) (2000). Corruption and development in Africa: Lessons from country case-studies. Macmillan Press.

34. Idahosa, P. (2002). Business ethics and development in conflict (zones): the case of Talisman Oil. Journal of Business Ethics, 39(3), 227-246. https://doi.org/10.1023/A:1016546308886 
35. Idemudia, U. (2007). Community perceptions and expectations: reinventing the wheels of corporate social responsibility practices in the Nigerian oil industry. Business and Society Review, 112(3), 369405. https://doi.org/10.1111/j.1467-8594.2007.00301.x

36. Idemudia, U., \& Ite, U. E. (2006). Corporate-community relations in Nigeria's oil industry:

37. challenges and imperatives. Corporate Social Responsibility and Environmental Management,13(4),194-206. https://doi.org/10.1002/csr.101

38. Jamali, D. (2010). The CSR of MNC subsidiaries in developing countries: global, local, substantive, or diluted. Journal of Business Ethics,93(2), 181-200. https://doi.org/10.1007/s10551-010-0560-8

39. Kapelus, P. (2002). Mining, corporate social responsibility, and the "community": the case of Rio Tinto, Richards Bay Minerals, and the Mbonambi. Journal of Business Ethics, 39(3), 275-296. https://www.jstor.org/stable/25074842

40. Kastning, T. (2017). Basic overview of Ghana's emerging oil industry. oilandgasirc.org.gh/2017/04/basic-overview-of-ghanasemerging-oil-industry/

41. Khanna, T., \& Palepu, K. G. (2005, June). Emerging giants: Building world-class companies in emerging markets. Harvard Business Review, 37-45.

42. Khanna, T. \& Palepu, K. G. (2010). The nature of institutional voids in emerging markets', in T. Khanna and K. G. Palepu (eds), Winning in Emerging Markets: A Road Map for Strategy and Execution: 1326. Harvard Business Press.

43. Khanna, T., \& Palepu, K.G. (1997). Why focused strategies may be wrong for emerging Markets. Harvard Business Review, 75(4), 4151.

44. Khanna, T., Palepu, K. G., \& Sinha, J. (2005, June). Strategies that fit emerging markets. Harvard Business Review, 4-19.

45. Kolk, A. (2016). The social responsibility of international business: from ethics and the environment to CSR and sustainable development. Journal of World Business, 51(1), 23-34. https://doi.org/10.1016/j.jwb.2015.08.010

46. Kolk, A., Kourula, A., \& Pisani, N. (2017). Multinational enterprises and the sustainable development goals: What do we know and how to proceed? Transnational Corporations, 24(3), 9-32. https://ssrn.com/abstract=2988607 
47. Kolk, A., \& Lenfant, F. (2010). MNC reporting on CSR and conflict in Central Africa. Journal of Business Ethics, 93(2), 241-255. https://doi.org/10.1007/s10551-009-0271-1

48. Kolk, A., \& Lenfant, F. (2013). Multinationals, CSR, and partnerships in Central African conflict countries. Corporate Social Responsibility and Environmental Management, 20(1), 43-54. https://doi.org/10.1002/csr.1277

49. Kolk, A., \& Lenfant, F. (2015a). Partnerships for peace and development in fragile states: identifying missing links. Academy of Management Perspectives, 29(4), 422-437. https://doi.org/10.5465/amp.2013.0122

50. Kolk, A., \& Lenfant, F. (2015b). Cross-sector collaboration, institutional gaps, and fragility: The role of social innovation partnerships in a conflict affected region. Journal of Public Policy \& Marketing, 34(2), 287-303. https://doi.org/10.1509/jppm.14.157

51. Kolk, A., \& Lenfant, F. (2018). Responsible business under adverse conditions: Dilemmas regarding company contributions to local development. Business Strategy Development, 1(1), 8-16. https://doi.org/10.1002/bsd2.5

52. Kosmos Energy website (2018). Company profile. http://www.kosmosenergy.com/pdfs/company_profiles/Profile_Engli sh.pdf

53. Kourula, A., Pisani, N., \& Kolk, A. (2017). Corporate sustainability and inclusive development: Highlights from international business and management research. Current Opinion in Environmental Sustainability, 24,14-18. https://doi.org/10.1016/j.cosust.2017.01.003

54. Lenfant, F. (2016). On Business, Conflict and Peace: Interaction and Collaboration in Central Africa. Unpublished $\mathrm{PhD}$ Thesis, University of Amsterdam, The Netherlands.

55. Mulwa, R. (2017). Natural resource curse and its causation channels in Africa. African Journal of Economic and Sustainable Development, 6(4), 244-261. DOI:10.1504/AJESD.2017.094859

56. Meyer, K. E. (2004). Perspectives on multinational enterprises in emerging economies. Journal of International Business Studies, 35(4), 259-276. https://doi.org/10.1057/palgrave.jibs.8400084

57. Meon, P-G., \& Sekkat, K. (2005). Does corruption grease or sand the wheels of growth? Public Choice, 122(1-2), 69-97. https://doi.org/10.1007/s11127-005-3988-0

58. Ministry of Finance, Ghana (2019). GHEITI Report on the Oil and Gas Sector 2017-2018. 
59. Newell, P., \& Frynas, J. G. (2007). Beyond CSR, business, poverty, and social justice: an Introduction. Third World Quarterly, 28(4), 669-681. https://doi.org/10.1080/01436590701336507

60. Ochieng, N.T., Wilson, K., Derrick, C.J., \& Mukherjee, N. (2018). The use of focus group discussion methodology: Insights from two decades of application in conservation. Methods in Ecology and Evolution, 9(1), 20-32. https://doi.org/ 10.1111/2041-210X.12860

61. Oetzel, J., \& Doh, J. P. (2009). MNEs and development: a review and reconceptualization. Journal of World Business, 44(2), 108-120. https://doi.org/10.1016/j.jwb.2008.05.001

62. Ofori-Atta, K. (2018). 2017 Reconciliation report on the petroleum holding fund submitted to Parliament in fulfilment of the requirement of section 15 of the Petroleum Revenue Management Act, 2011 (Act 815) As amended (Act 893), Accra https://www.mofep.gov.gh/sites/default/files/reports/petroleum/2017Petroleum-Annual-Report_2018-03-26.pdf

63. Ogundiya, I.S. (2010). Democracy and good governance: Nigeria's dilemma. African Journal of Political Science and International Relations, 4(6), 201-208.

64. Osuji, O. K., \& Obibuaku, U. L. (2016). Rights and corporate social responsibility: Competing or complementary approaches to poverty reduction and socioeconomic rights? Journal of Business Ethics, 136(2), 329-347. https://doi.org/10.1007/s10551-014-2523-y

65. Parmigiani, A., \& Rivera-Santos, M. (2015). Sourcing for the Base of the Pyramid: Constructing supply chains to address voids in subsistence markets. Journal of Operations Management, 33/34, 6070. https://doi.org/10.1016/j.jom.2014.10.007

66. Patton, M.Q. (2002). Qualitative research and evaluation methods (3rd edn). Sage Publications.

67. Pisani, N., Kourula, A., Kolk, A., \& Meijer, R. (2017). How global is international CSR research? Insights and recommendations from a systematic review. Journal of World Business, 52(5), 591-614. https://doi.org/10.1016/j.jwb.2017.05.003

68. Pitelis, C.N., \& Teece, D. J. (2009). The (New) Nature and Essence of the Firm. European Management Review, 6(1), 5-15. https://doi.org/10.1057/emr.2009.1

69. Planitz, E., \& Kuzu, D. (2015). Oil production and the transformation of livelihoods of communities in Ghana. Friedrich Ebert Stiftung \& You-net Report. http://www.fesghana.org/uploads/PDF/FINAL_Study_OilLivelihood.pdf 
70. Pouw, N., \& Gupta, J. (2017). Inclusive development: A multidisciplinary approach. Current Opinion in Environmental Sustainability, 24, 104-108. https://hdl.handle.net/11245.1/067134594162-4850-b5d3-4b7d340f509a

71. Prahalad, C.K., \& Ramaswamy, V. (2004). Co-creating unique value with customers. Strategy \& Leadership, 32(3), 4-9. DOI: $10.1108 / 10878570410699249$

72. Reed, D. (2002). Resource extraction industries in developing countries. Journal of Business Ethics, 39(3), 199-226. https://doi.org/10.1023/A:1016538006160

73. Reichardt, M., \& Reichardt, C. L. (2006). Tracking sustainability performance through company reports: a critical review of the South African mining Sector. In W. Visser, M. McIntosh, \& C. Middleton (Eds.). Corporate Citizenship in Africa: Lessons from the Past; Paths to the Future, Greenleaf Publishing, pp.171-189.

74. Reinecke, J., \& Ansari, S. (2016). Taming wicked problems: the role of framing in the construction of corporate social responsibility. Journal of Management Studies, 53(3), 299-329. https://doi.org/10.1111/joms.12137

75. Ritchie, J., \& Lewis. J. (eds.) (2003). Qualitative research practice: A guide for Social Science students and researchers. Sage Publications.

76. Romero, D., \& Molina, A. (2011). Collaborative networked organisations and customer communities: Value co-creation and coInnovation in the networking era. Journal of Production Planning \& Control, 22(5-6), 447-472. https://doi.org/10.1080/09537287.2010.536619

77. Scherer, A. G., Rasche, A., Palazzo, G., \& Spicer, A. (2016). Managing for political corporate social responsibility: new challenges and directions for PCSR 2.0. Journal of Management Studies, 53(3), 273-298. https://doi.org/10.1111/joms.12203

78. Sekondi-Takoradi Metropolitan Assembly (2016). Profile of the metropolis. https://www.wrcc.gov.gh/en/mmda-s/metropolitan/stma

79. Sluiter, L. (2009). Clean Clothes. A Global Movement to End Sweatshops. Pluto Press.

80. Suleiman, M.N., \& Karim, M.A. (2015). Cycle of bad governance and corruption: The rise of Boko Haram in Nigeria. SAGE Journals, 5(1), 1-11. https://doi.org/10.1177/2158244015576053

81. Sullivan, R. (Ed.) (2003). Business and Human Rights. Greenleaf Publishing. 
82. Tanzi, V. (1998). Corruption around the world: Causes, consequences, scope, and cures. IMF Staff Papers, 45(4), 559-594. DOI: $10.2307 / 3867585$.

83. Tong, A., Sainsbury, P., \& Craig, J. (2007). Consolidated criteria for reporting qualitative

84. research (COREQ): A 32-item checklist for interviews and focus groups. International

85. Journal for Quality in Health Care, 19(6), 349-357. https://doi.org/10.1093/intqhe/mzm042

86. Tullow Oil (2018). Company profile. https://www.tullowoil.com/operations/west africa/ghana

87. Turner, M. (2006). Taming mammon: corporate social responsibility and the global regulation of conflict trade. Conflict, Security \& Development, $6(3)$ 365-387. https://doi.org/10.1080/14678800600933530

88. United Nations (2013). Africa Economic Outlook. New York.

89. United Nations (2015). Resolution adopted by the General Assembly on $25 \quad$ September 2015. A/RES/70/1.https://sustainabledevelopment.un.org/post2015/transfor mingourworld3.

90. United Nations (2016) Human Development Report. New York.

91. Van de Ven, A.H. (2007). Engaged scholarship. A guide for organizational and social research. Oxford University Press.

92. Visser, W. (2002). Sustainability reporting in South Africa. Corporate Environmental Strategy, 9(1), 79-85. https://doi.org/10.1016/S1066-7938(01)00157-9

93. Watts, M. (2005). Righteous oil? Human rights, the oil complex and corporate social responsibility. Annual Review of Environment and Resources, $30(1)$ 373-407. http://globetrotter.berkeley.edu/GreenGovernance/papers/Watts_Righ teousOil.pdf

94. Wheeler, D., Fabig, H., \& Boele, R. (2002). Paradoxes and dilemmas for stakeholder responsive firms in the extractive sector: lessons from the case of Shell and the Ogoni. Journal of Business Ethics, 39(3), 297-318. https://doi.org/10.1023/A:1016542207069

95. Whelan, G. (2012). The political perspective of corporate social responsibility: A critical research agenda. Business Ethics Quarterly, 22(4), 709-737. DOI: https://doi.org/10.5840/beq201222445 
96. Wickert, C. M. J. (2016). Political Corporate Social Responsibility in small and medium- sized enterprises: A conceptual framework. Business and Society, 55(6), 792-824. https://doi.org/10.1177/0007650314537021

97. Yin, R. K. (2009). Case Study Research: Design and Methods (4th ed.). Sage Inc. 